\title{
Pengaruh Dana Pihak Ketiga dan Non-Performing Loan terhadap Penyaluran Kredit pada Bank yang Terdaftar di BEI
}

\author{
The effect of third party funds and non-performing loans on bank credit distribution of banks listed \\ on the IDX
}

\section{Popy Sandra Tesalonica Hutahaean}

Program Studi D3 Keuangan dan Perbankan, Politeknik Negeri Bandung

E-mail: popysanth@gmail.com

\section{Diharpi Herli Setyowati}

Jurusan Akuntansi, Politeknik Negeri Bandung

E-mail: diharpi@yahoo.com

\section{Endang Hatma Juniwati}

Jurusan Akuntansi, Politeknik Negeri Bandung

E-mail: endang.hatma@polban.ac.id

\begin{abstract}
The purpose in this research was to find the effect of third party funds and non-performing loans on the amount of lending to banking sector listed on the Indonesia Stock. Exchange for the period 2014 to 2018. The research method used is quantitative descriptive method. The data used are secondary data in the form of annual financial reports, and the data analysis technique uses multiple linear regression analysis. The data processing in this study used a statistical tool, namely E-views 9. The results of this study indicate that partially third party funds have a positive and significant effect on the amount of lending and non-performing loans bave a negative and significant effect on the amount of credit disbursement. Simultaneously or together, third party funds and nonperforming loans bave a significant effect on the amount of lending.
\end{abstract}

Keywords: third party funds, non-performing loan, credit

\section{Pendahuluan}

Bank adalah badan perantara keuangan bagi pihak kelebihan dana dengan pihak kekurangan dana. Dananya yang berlebih tersebut dialirkan untuk kelompok yang membutuhkan dan memberikan keuntungan pada kelompok tersebut (Dendawijaya, 2005). Lembaga perbankan akan semakin diperlukan untuk menumbuhkan ekonomi nasional melalui penyediaan berbagai fasilitas seperti penyediaan kredit maupun fasilitas lainnya yang memudahkan masyarakat dalam lalu lintas pembayaran sehingga bank memegang peranan penting bagi pembangunan dan sistem perekonomian. Secara garis besar pembangunan ekonomi tidak bisa lepas dari sektor perbankan, apabila suatu saat unit perbankan merosot maka ekonomi nasional juga, dan sebaliknya apabila perdagangan mengalami kelumpuhan fungsi intermediasi unit perbankan tidak akan berjalan normal (Kiryanto, 2007).

Masyarakat yang dananya berlebih mampu menyimpan uangnya dalam wujud giro, deposito, tabungan, dan sebagainya yang menyerupai atau dikenal dengan dana pihak ketiga. Giro, tabungan, dan deposito adalah simpanan nasabah yang dikumpulkan oleh bank dengan menawarkan berbagai produk inovatif pada masyarakat, yang taruh kepercayaannya pada unit perbankan untuk 
menyimpan uangnya dimana saat jatuh tempo akan ditarik kembali dengan imbalan bunga dari bank tersebut (Mulyono, 2007).

Sumber dana dari masyarakat adalah penghimpunan dana terbesar yang sangat diyakinkan unit perbankan hingga mampu mencapai $80 \%-90 \%$ dari semua dananya yang dioperasikan oleh unit perbankan (Dendawijaya, 2005). DPK akan mampu mempengaruhi penyaluran kredit karena memberikan sumbangan dana terbesar dari sumber dana yang berhasil dikumpulkan oleh unit keuangan (Kasmir, 2008). Menyalurkan kembali dananya kepada masyarakat atau disebut kredit merupakan aktivitas perbankan sesudah menghimpun dananya dari masyarakat (Kasmir, 2008). Aktivitas penyaluran kredit ini adalah kegiatan operasi perbankan yang fundamental untuk mendapatkan laba (Dendawijaya, 2005).

Berdasarkan Ikatan Akuntan Indonesia kredit adalah tagihan biaya yang bisa disamakan dengan itu atas persetujuan atau kesepakatan kedua pihak antara perbankan dan pihak lain yang mengharuskan debitur membayar hutangnya sampai batas waktu tertentu dan dikenai bunga, imbalan, atau pembagian hasil profit. Penyaluran kredit yang dioperasikan unit perbankan juga menyebabkan resiko kredit bersifat macetnya pengembalian pinjaman atau disebut Non Performing Loan. Kredit bermasalah yaitu rasio untuk menilai kemampuan bank dalam menutupi risiko kegagalan kembalinya pinjaman oleh peminjam (Darmawan, 2004).

Bagian kehidupan bisnis bank yaitu kredit bermasalah disebabkan salah satunya peminjam tidak dapat memberikan bunga dan mengembalikan pinjamannya (Suhardjono, 2003). Kredit bermasalah tidak lepas juga dari kesalahan pihak perbankan dalam menganalisis debiturnya sehingga tidak hati-hati saat menyalurkan kredit. Sulitnya penyaluran kredit salah satunya disebabkan pada tingginya NPL (Sentausa, 2009). Kredit bermasalah yang tinggi juga mengakibatkan dananya semakin kecil karena perbankan wajib membangun cadangan penghapusan yang makin banyak (Meydianawhati, 2007).

Tabel dibawah ini menunjukkan pertumbuhan DPK, NPL, dan Jumlah Pemberian Kredit untuk 4 perusahaan perbankan yang tercatat di BEI periode 2014-2018.

Tabel 1 DPK, Penyaluran Kredit dan NPL Pada Perusahaan Perbankan yang tercatat di Bursa Efek Indonesia

(dalam jutaan rupiah)

\begin{tabular}{|c|r|r|r|r|}
\hline Nama Bank & Tahun & DPK & Kredit & \multicolumn{1}{c|}{ NPL } \\
\hline \multirow{4}{*}{ CIMB Niaga } & 2014 & $174,723,234$ & $163,623,334$ & $3,11 \%$ \\
\cline { 2 - 5 } & 2015 & $178,533,077$ & $163,682,732$ & $3,74 \%$ \\
\cline { 2 - 5 } & 2016 & $180,571,134$ & $165,923,435$ & $3,89 \%$ \\
\cline { 2 - 5 } & 2017 & $189,317,196$ & $174,421,016$ & $3,75 \%$ \\
\cline { 2 - 5 } & 2018 & $190,750,218$ & $180,311,277$ & $3,90 \%$ \\
\hline \multirow{4}{*}{ OCBC NISP } & 2014 & $72,805,057$ & $66,933,612$ & $1,34 \%$ \\
\cline { 2 - 5 } & 2015 & $87,280,244$ & $84,040,768$ & $1,30 \%$ \\
\cline { 2 - 5 } & 2016 & $103,559,960$ & $90,247,652$ & $1,88 \%$ \\
\cline { 2 - 5 } & 2017 & $113,440,672$ & $102,189,794$ & $1,79 \%$ \\
\hline \multirow{3}{*}{ Mega } & 2018 & $125,560,448$ & $113,490,896$ & $1,73 \%$ \\
\cline { 2 - 5 } & 2014 & $51,021,875$ & $33,679,790$ & $2,09 \%$ \\
\cline { 2 - 5 } & 2015 & $49,739,672$ & $31,748,472$ & $2,81 \%$ \\
\hline
\end{tabular}




\section{Popy Sandra Tesalonica Hutahaen, Diharpi Herli Setyowati, Endang Hatma Juniwati}

\begin{tabular}{|c|r|r|r|r|}
\hline Nama Bank & \multicolumn{1}{|c|}{ Tahun } & \multicolumn{1}{c|}{ DPK } & \multicolumn{1}{c|}{ Kredit } & \multicolumn{1}{c|}{ NPL } \\
\hline & 2017 & $61,283,141$ & $35,237,814$ & $2,01 \%$ \\
\cline { 2 - 5 } & 2018 & $60,734,798$ & $42,263,704$ & $1,60 \%$ \\
\hline \multirow{4}{*}{ Danamon } & 2014 & $116,495,224$ & $106,751,141$ & $2,35 \%$ \\
\cline { 2 - 5 } & 2015 & $115,141,528$ & $99,483,055$ & $3,00 \%$ \\
\cline { 2 - 5 } & 2016 & $103,609,069$ & $91,888,516$ & $3,10 \%$ \\
\cline { 2 - 5 } & 2017 & $101,896,818$ & $94,045,506$ & $2,80 \%$ \\
\cline { 2 - 5 } & 2018 & $107,695,796$ & $101,650,553$ & $2,70 \%$ \\
\hline
\end{tabular}

Sumber : laporan keuangan yang diolah

Tabel 1 diatas memperlihatkan bahwa DPK dan jumlah kredit di CIMB Niaga dan OCBC NISP terus mengalami peningkatan yang artinya dana pihak ketiga searah dengan pergerakan jumlah kredit, sedangkan pada Bank Mega dan Bank Danamon DPK yang dikumpulkan unit tersebut dan pinjaman yang diberikan cenderung berfluktuatif. DPK PT Bank Mega Tbk untuk tahun 2016 meningkat dari tahun lalu menjadi Rp 51.073.227.000.000,- akan tetapi kredit yang diberikan mengalami penurunan menjadi Rp 28.300.130.000.000,- dan pada tahun 2018 dana pihak ketiga bank Mega mengalami penurunan akan tetapi kreditnya mengalami peningkatan. Pada PT Bank Danamon Indonesia Tbk, ketika dana pihak ketiga menurun di tahun 2017, jumlah penyaluran kreditnya mengalami peningkatan dari Rp 91,888,516.000.000,- menjadi Rp 94.045.506.000.000,-. Dari fenomena tersebut yang terjadi ketika simpanan nasabah meningkat jumlah kreditnya menurun dan sebaliknya, hal tersebut bertolakbelakang dengan teori yang ada, yaitu makin besar DPK yang mampu dikumpulkan, maka makin besar kreditnya. Pada hakikatnya dana pihak ketiga berhubungan positif terhadap jumlah kredit/pinjaman.

Beberapa karya ilmiah sebelumnya antara lain dilakukan oleh Agus Murdiyanto (2011) dengan judul "Faktor - Faktor Yang Berpengaruh Dalam Penentuan Penyaluran Kredit Bank (Studi Pada Bank Umum di Indonesia Periode Tahun 2006-2011)". Hasilnya menyimpulkan DPK memiliki hubungan positif signifikan terhadap kredit/pinjaman. Hal tersebut bertentangan pada hasil penelitian yang dibuat Setiyati yang mana DPK berhubungan negatif signifikan terhadap kredit.

Tabel 1 diatas juga memperlihatkan rasio kredit.bermasalah (NPL) 4 perusahaan perbankan yang tercatat di BEI berada dibawah batas maximum yang telah ditetapkan BI yaitu 5\%. Pada Bank CIMB Niaga rasio kredit bermasalah (NPL) mengalami kenaikan setiap tahunnya searah dengan peningkatan penyaluran kredit bank tersebut, sedangkan pada PT Bank Mega Tbk peningkatan NPL tertinggi terjadi di tahun 2016 yaitu sebesar 3,44\%. Namun, pada tahun 2017-2018 PT Bank Mega Tbk mampu menurunkan NPL yang dapat merugikan bank. Bank Danamon pada tahun 2014-2016, rasio kredit bermasalah (NPL) mempunyai pergerakan meningkat yang tidak selaras dengan perkembangan kredit, dan punya perkembangan NPL yang turun dari tahun 2017-2018 juga tidak sejalan dengan arah pertumbuhan kreditnya. Bank OCBC NISP rasio kredit bermasalah (NPL) tahun 2015 mengalami penurunan tidak searah dengan pergerakan kredit. Namun pada tahun 2016, NPL mengalami pergerakan yang meningkat sejalan dengan pertumbuhan kreditnya dan punya dinamika menurun dari tahun 2017-2018.

Fenomena yang terjadi diatas, tidak sesuai pada teori yang sudah diutarakan oleh para ahli sebelumnya. Menurut (Soedarto, 2004) Non Performing Loan (NPL) memiliki hubungan positif signifikan terhadap kredit sektor bank sedangkan penelitian yang dibuat oleh (Pratama, 2010), (Mukhlis, 2011), dan Yuliana (2014) mengungkapkan yaitu Non Performing Loan (NPL) berhubungan negatif signifikan dengan penyaluran kredit. 
Berdasarkan fenomena dan research gap dari hasil karya ilmiah terdahulu, penulis tertarik untuk melakukan penelitian dengan judul "Pengaruh Dana Pihak Ketiga dan Non-Performing Loan terhadap Penyaluran Kredit pada Bank yang Terdaftar di BEI”.

\section{Kajian Pustaka}

\subsection{Pengertian Bank}

Bank merupakan badan usaha yang mengumpulkan dana dari masyarakat dengan bentuk simpanan dan memberikannya kembali kepada masyarakat dengan bentuk kredit dan atau bentuk lainnya dalam rangka meningkatkan taraf hidup rakyat banyak (UU No. 10 Tahun 1998). Secara garis besar unit bank hanya sebagai badan intermediasi keuangan saja, kegiatan operasional perbankan menjadi terhambat tanpa adanya himpunan dana dari nasabah.

\subsection{Dana Pihak Ketiga}

Sumber pendanaan yang dikumpulkan dari masyarakat atau yang dikenal oleh DPK adalah sumber dana terbesar yang paling diyakinkan bank hingga sampai 80\%-90\% dari total dana-dana yang dioperasikan pihak perbankan (Dendawijaya, 2005). Berdasarkan UU RI No.10 Tahun 1998 Tentang Perbankan, menyebutkan dana masyarakat yang dipercayakan pada pihak bank berdasarkan kesepakatan simpanan uang dalam bentuk giro, tabungan, dan deposito serta yang lainnya disebut dana pihak ketiga.

\subsection{Kredit}

Kredit diambil dari bahasa Yunani, credere artinya kepercayaan, atau dari Bahasa Latin, creditum artinya kepercayaan akan kebenaran (Kasmir, 2008). Mengacu pada UU No.10 Tahun 1998, penyediaan uang atau tagihan yang bisa disamakan dengan itu berasaskan persetujuan simpanpinjam untuk membayar utangnya sampai batas waktu tertentu dengan total bunga disebut kredit.

\section{$2.4 \quad$ Non-Performing Loan}

NPL adalah rasio yang ditetapkan untuk mengukur kemampuan bank dalam menutupi resiko kegagalan pengembalian pinjaman oleh peminjam (Darmawan, 2004). Kredit bermasalah lebih dari sekadar penilaian ketidakmampuan debitur untuk melunasi utangnya, tetapi menjadi biaya baik bagi kreditur maupun debitur (Balgova, 2016). Setiap bank wajib menjaga NPL-nya dibawah 5\% sehingga kinerja berapor biru, hal ini selaras dengan ketetapan Bank Indonesia.

Berdasarkan Surat Edaran BI No.6/23/DPNP rumus NPL adalah sebagai berikut:

$$
\mathrm{NPL}=\frac{\text { Kredit dalam kualitas kurang lancar,diragukan dan macet }}{\text { Total Kredit }} \times 100 \%
$$

\subsection{Kerangka Pemikiran}

Bank adalah badan perantara yang menghimpun dana dari masyarakat serta menyalurkan kembali berupa kredit pada masyarakat. Dalam melaksanakan fungsi perbankan sebagai perantara keuangan, maka penghimpunan dana merupakan aktivitas utama sebelum menyalurkan dana-dana pada masyarakat. Sumber pendanaan utamanya berasal dari dana masyarakat yang dikumpulkan pada bentuk simpanan deposito berjangka, tabungan, dan giro (Abdullah, 2005).

Penyaluran kepada masyarakat adalah kegiatan operasional setelah pengumpulan dana-dana dari masyarakat. Proporsi terbesar saluran dana berasal dari pinjaman/kredit. Pemberian pinjaman/kredit merupakan aktivitas utama perbankan untuk mendapat laba, tetapi risiko besar pula dihadapi perbankan dalam pemberian kreditnya. Risiko kredit inilah yang dinilai dengan rasio NPL. NPL merupakan perbandingan jumlah kredit bermasalah terhadap total kredit yang diberikan. Dengan munculnya kredit bermasalah tentunya dapat menghambat bank dalam memperoleh keuntungan (profit). 
Berikut gambaran yang sistematis untuk alur kerangka berpikir pada penelitian yang dilakukan ini.

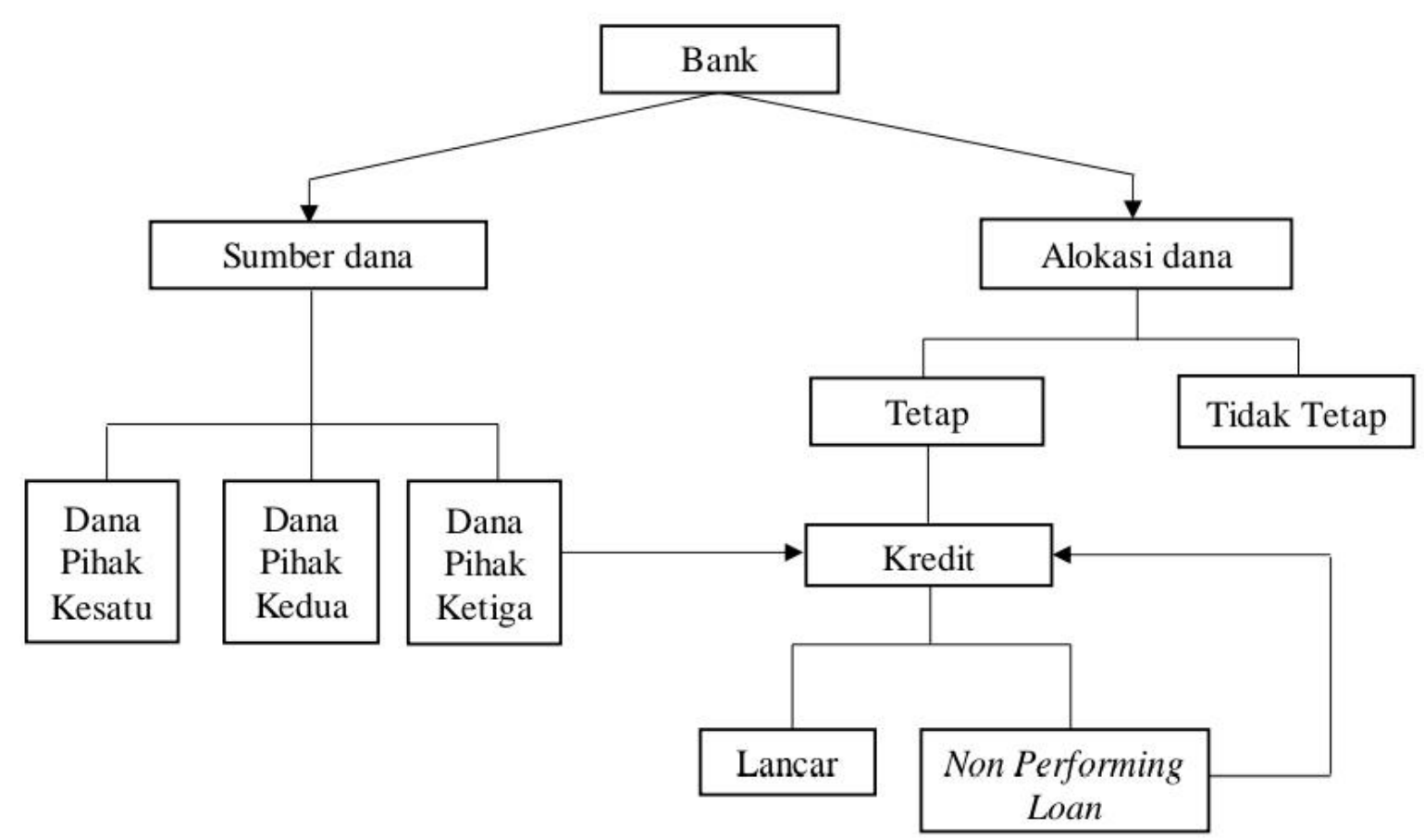

Gambar 2 Kerangka Pemikiran

\section{Metode Penelitian}

Metode penelitian ini menerapkan pendekatan kuantitatif. Pendekatan kuantitatif adalah pengukuran variabel-variabel yang ada, untuk selanjutnya dibuat hubungan antar variable tersebut. Pada penelitian ini, variable independentnya yaitu DPK dan NPL sementara untuk variable dependentnya yaitu penyaluran kredit.

\section{Jenis dan Sumber Data}

Jenis data penelitian menggunakan data sekunder dan sumber data pada penelitian ini diambil dari laporan keuangan yang diterbitkan melalui situs Bursa Efek Indonesia oleh bank-bank yang tercatat di BEI dan terdiri dari laporan keuangan tahunan untuk periode tahun 2013 hingga 2018.

\section{Teknik Analisis}

Cara analisis datanya mengenakan analisis regresi berganda yang dipakai untuk mengolah data sebagai berikut.

\section{Statistik Deskriptif}

Penguraian statistik deskriptif digunakan untuk menghitung nilai min., max., dan mean, pada variable independent DPK dan NPL serta variable dependent jumlah penyaluran kredit untuk sektor bank yang tercatat di BEI tahun 2014-2018.

2. Uji Pemilihan Model Terbaik

Pembahasan model regresi pada tahap ini menggunakan teknik CEM, FEM, dan REM. Pegujian model terbaik digunakan dengan 2(dua) cara yaitu Uji Chow dan Uji Hausman.

3. Uji Asumsi Klasik 
Berikut tahap-tahap pengujian asumsi klasik.

a. Uji Normalitas

Pengujian ini menggunakan uji Jarque-Bera. Uji JB dikatakan normal apabilai angka probabilitas $>5 \%$ atau $>0,05$ (Ghozali, 2009). Apabilai nilai signifikansinya $<5 \%$ atau $<0,05$ maka distribusi datanya dikatakan tidak normal.

b. Uji Multikolinieritas

Uji multikolinieritas dimaksudkan untuk mengetahui ada atau tidaknya korelasi antar variable independent. Caranya yaitu dengan menemukan adanya gejala multikol yaitu dengan mengetahui koefisien korelasi, apabila $<0,8$ maka tidak terdapat multikolinieritas (Gujarati, 2006).

c. Uji Heteroskedastisitas

Pengujian tahap ini menggunakan uji Glejser dengan melakukan regresi antara nilai variable independent dan absolute residual sebagai dependent. Apabila angka signifikan antara variable independent dengan absolute residual $>0,05$ maka tidak terjadi masalah heteroskedastisitas (Gujarati, 2006).

d. Uji Autokorelasi

Dalam penelitian ini upaya mendeteksi autokorelasi menggunakan table Durbin Watson. Tidak terdapat autokorelasi positif dan negatif apabila angka dari Durbin Watson lebih dari batas atas (dU) dan kurang dari 4 dikurangi batas atas atau dU $<$ DW $<4$-dU.

4. Uji Hipotesis

a. Uji t

Uji hipotesis dengan uji t pada dasarnya untuk menemukan besaran pengaruh satu variable independent secara individual dalam menjelaskan variasi variable dependen. Pengambilan keputusan dalam penerimaan atau penolakan hipotesis ini dapat ditulis sebagai berikut:

Apabila angka t-hitung $>\mathrm{t}$-table atau angka probabilitas $\mathrm{t}<\alpha=0,05$ maka $\mathrm{H} 0$ ditolak, sehingga disimpulkan variable independent secara parsial signifikan berpengaruh pada variabel dependen (Gujarati, 2006).

b. Uji F

Tahap ini menguji bagaimana variabel-variable independent secara bersamaan signifikan terhadap variable dependen. Proses ini dilaksanakan dengan melihat perbandingan angka F-hitung beserta F-tabel. Jika F-hitung $>$ F-tabel maka $\mathrm{H} 0$ tidak diterima, artinya variable independent secara bersamaan memengaruhi variable dependen.

\section{Hasil dan Pembahasan}

\subsection{Statistik Deskriptif}

Tabel 2 Hasil Output Statistik Deskriptif

\begin{tabular}{|l|r|r|r|}
\hline & \multicolumn{1}{|c|}{ DPK } & \multicolumn{1}{|c|}{ NPL } & \multicolumn{1}{c|}{ KYD } \\
\hline Mean & $77.295 .533,76874991$ & 2,7820625 & $69.878 .649,85000005$ \\
\hline Median & 18.286 .772 & 2,365 & $14.807 .129,5$ \\
\hline Maximum & 915.430 .199 & 15,82 & 820.010 .157 \\
\hline Minimum & 1.204 .317 & 0 & 141.304 \\
\hline
\end{tabular}

Sumber: data diolah

Tabel 2 diatas memperlihatkan rata-rata penyaluran kredit secara keseluruhan ada di angka 69.878.649 (juta rupiah) dengan angka maksimal ada di angka 820.010.157 (juta rupiah) dan angka terendah ada di angka 141.304 (juta rupiah). Sementara rata-rata DPK secara keseluruhan ada di angka 77.295.533 (juta rupiah) dan angka maksimal ada di angka 915.430.199 (juta rupiah) dan angka terendahnya ada pada angka 1.204.317 (juta rupiah). Berdasarkan tabel 2, dapat juga didapati 
bahwa rata-rata rasio NPL adalah senilai 2,7820625\% dengan nilai tertinggi ada di angka 15,82\% dan nilai terendah ada pada nilai 0 (nol).

\subsection{Uji Pemilihan Model Terbaik}

Tabel 3 Hasil Uji Chow dan Uji Hausman

\begin{tabular}{|l|l|l|}
\hline \multicolumn{1}{|c|}{ Uji Model Terbaik } & \multicolumn{1}{c|}{ Nilai Probabilitas } & Hasil Hipotesis \\
\hline Uji Chow & 0,0000 & Tolak Ho, maka FEM \\
\hline Uji Hausman & 0,0000 & Tolak Ho, maka FEM \\
\hline
\end{tabular}

Sumber: hasil olah data E-views 9.0

Tabel 3 diatas menunjukkan bahwa nilai probabilitas hasil Uji Chow adalah 0,0000 yang mana < taraf nyata yakni 5\% maka Ho ditolak, artinya model FEM lebih baik digunakan dibandingkan CEM. Hasil Uji Hausman ditunjukkan nilai probabilitas 0,0000 yang juga $<5 \%$. Oleh karena itu, disimpulkan bahwa Ho ditolak, artinya model FEM lebih baik digunakan dibandingkan REM.

\subsection{Uji Asumsi Klasik}

1. Uji Normalitas

Tabel 4 Hasil Uji Normalitas Jarque Bera

\begin{tabular}{|l|l|l|}
\hline Uji Normalitas & Nilai & Keterangan \\
\hline Jarque Bera & 4,2183 & $>$ taraf nyata $5 \%$ \\
\hline Probability & 0,1213 & $>$ taraf nyata $5 \%$ \\
\hline
\end{tabular}

Sumber: hasil olah data E-views 9.0

Berdasarkan table 4 dapat dilihat bahwa nilai probabilitas Jarque-Bera senilai 0,1213 sehingga $0,1213>0,05$, artinya data-data dalam penelitian telah terdistribusi normal.

2. Uji Multikolineritas

Berdasarkan hasil uji multikolinieritas, menyimpulkan model regresi terbebas dari masalah multikolinieritas, hal ini dilihat dari matriks korelasi antara semua variabel independennya memiliki nilai koefisien matriks kurang dari 0,8 yaitu sebesar -0,057625.

3. Uji Heteroskedastisitas

Tabel 5 Hasil Uji Park

\begin{tabular}{|ccccc|}
\hline \multicolumn{5}{|c|}{ Dependent Variable: RESABS } \\
\hline \multicolumn{5}{|c|}{ Method: Panel EGLS (Cross-section weights) } \\
\hline Variable & Coefficient & Std. Error & t-Statistic & Prob. \\
C & 683322.5 & 429179.3 & 1.592161 & 0.1139 \\
DPK & 0.016483 & 0.005623 & 2.931575 & 0.0040 \\
NPL & 22453.23 & 8955.084 & 2.507317 & 0.0134 \\
\hline
\end{tabular}

Sumber: hasil olah data E-views 9.0

Tabel 5 diatas memperlihatkan angka probabilitas yakni 0,0040 dan 0,0134<0,05. Sehingga disimpulkan untuk model estimasi mengandung masalah heteroskedastisitas. Apabila model mengalami gejala heteroskedastisitas, dan menggunakan metode GLS Weight Cross-section weights 
masalah terselesaikan dan model estimasi dikatakan sudah terbebas dari gejala heteroskedastisitas. Permasalahan heteroskedastisitas mampu diperbaiki dengan menggunakan metoda Generalized Least Square (EGLS) jadi gejala heteroskedastisitas pada model bisa ditoleransi (Hill, R.C, 2008).

4. Uji Autokorelasi

Berdasarkan hasil uji Durbin Watson diperoleh angka dL senilai 1,7163 dan dU 1,7668. Dengan menemukan angka Durbin-Watson senilai 1,9560 dimana $\mathrm{dU}<\mathrm{d}<4-\mathrm{dU}$, maka dapat dikatakan tidak ada autokorelasi.

4.4 Analisis Regresi Berganda

Tabel 6 Hasil Regresi Pendekatan FEM Panel EGLS

\begin{tabular}{|l|l|l|l|c|}
\hline \multicolumn{5}{|c|}{ Dependent Variable: KYD } \\
\hline \multicolumn{5}{|c|}{ Method: Panel EGLS (Cross-section weights) } \\
\hline Variable & Coefficient & Std. Error & t-Statistic & Prob. \\
\hline C & -1.996 .173 & 1757505 & -1.135799 & 0.2582 \\
\hline DPK & 0.936670 & 0.023183 & 40.40271 & 0.0000 \\
\hline NPL & -188926.8 & 12510.46 & -15.10151 & 0.0000 \\
\hline R-squared & 0.998993 & & \\
Adjusted R-squared & 0.998730 & & \\
F-statistic & 3789.381 & & \\
Prob(F-statistic) & 0.000000 & & \\
Durbin-Watson stat & 1.956036 & & \\
\hline
\end{tabular}

Sumber: hasil olah data E-views 9.0

Berdasarkan tabel 6 yang merupakah hasil regresi, jadi persamaan regresi bergandanya yaitu: $\mathrm{KYD}=-1.996 .173+0,936670(\mathrm{DPK})-188.926,8(\mathrm{NPL})+\mathrm{e}$.

1. Nilai konstanta persamaan diatas menunjukkan nilai negatif sebesar -1.996 .173 (dalam juta rupiah), artinya jika semua variabel independen yaitu DPK dan NPL nilainya adalah 0, maka kredit nilainya adalah -1.996 .173 (dalam juta rupiah).

2. Variabel DPK memiliki hubungan positif dengan penyaluran kredit, dengan koefisien regresi sebesar 0,936670 (dalam juta rupiah). Hal ini mengindikasikan apabila DPK mengalami kenaikkan 1 satuan, maka kredit akan mengalami peningkatan 0,936670 (dalam juta rupiah) dengan anggapan variable NPL-nya tetap.

3. Variabel NPL mempunyai hubungan negatif dengan penyaluran kredit, dengan koefisien regresi sebesar -188.926,8 (dalam juta rupiah). Hal ini menyimpulkan pada NPL setiap naik 1 satuan maka kredit disalurkannya akan turun senilai 188.926,8 (dalam juta rupiah) dengan anggapan variable independent lain nilainya sama. 


\subsection{Uji Hipotesis}

1. Ujit

Tabel 7 Hasil Uji t

\begin{tabular}{|l|r|r|r|}
\hline \multicolumn{1}{|c|}{ Variabel } & t-statistik & t-tabel & Kesimpulan \\
\hline \multicolumn{4}{|c|}{ EGLS } \\
\hline DPK & 40,4027 & 1,6546 & H0 Ditolak \\
\hline NPL & $-15,1015$ & 1,6546 & H0 Diterima \\
\hline
\end{tabular}

Sumber: hasil olah data

a. Hubungan Dana Pihak Ketiga terhadap Penyaluran Kredit

Tabel 7 memperlihatkan dimana variabel Dana Pihak Ketiga angka t-hitungnya lebih besar dari angka t-tabelnya yaitu 40,4027>1,6546 dan angka signifikansi yakni $0,0000<0,05$, sehinggga kesimpulannya variabel DPK mempunyai hubungan positif signifikan pada penyaluran kredit.

Hasil penelitian ini menerangkan bahwa kenaikan atau turunnya DPK untuk tahun penelitian mempengaruhi jumlah saluran kreditnya penyaluran kredit dengan signifikan. Bertambah besarnya DPK yang berhasil dikumpulkan unit perbankan, akan memajukan tingkat jumlah saluran pinjaman/kredit, demikian pula sebaliknya.

DPK termasuk variable yang mempunyai pengaruh terbesar pada saluran kredit unit keuangan bank. Hal tersebut disebabkan saat melaksanakan fungsi intermediasi, DPK menyumbangkan dana-dana terbesar. Dana-dana yang dikumpulkan dari masyarakat mampu mencapai $80 \%-90 \%$ dari keseluruhan pendanaan yang diselenggarakan pihak perbankan (Dendawijaya, 2005).

Kesimpulan penelitian ini memperkuat hasil penelitian terdahulu yang diterapkan oleh (Pratama, 2010), Astuti (2013), (Annisa, 2015) dan (Erwin, 2016) yang menyimpulkan bahwa DPK mempunyai hubungan positif signifikan terhadap penyaluran kredit perbankan.

b. Pengaruh Non-Performing Loan (NPL) terhadap Penyaluran Kredit

Dari hasil uji t untuk variable Non-Performing Loan didapat angka t-hitung -15,1015<1,6546 dan angka signifikan sebesar $0,0000<0,05$, maka disimpulkan bahwa secara parsial variabel NPL berhubungan negatif signifikan terhadap penyaluran kredit.

Resiko kredit dicerminkan dengan NPL. Bertambahnya tingkat NPL maka resiko yang ditanggung pihak perbankan makin tinggi. Unit perbankan kemudian akan lebih efektif dalam penyaluran pinjaman/kredit. Kejadian tersebut terjadi karena adanya potensi kredit yang tidak tertagih. Bertambahnya NPL akan menyebabkan naikknya premi risiko yang berakibat pada tingginya suku bunga pinjaman. Peristiwa tersebut mampu mengurangi permintaan masyarakat akan kredit. Selain itu, bertambahnya tingkat NPL menyebabkan modal di unit keuangan terkikis karena pihak perbankan wajib menyediakan cadangan yang lebih besar. Sehingga hambatan penyaluran pinjaman/kredit salah satunya diakibatkan oleh besarkecilnya NPL.

Kesimpulan penelitian ini menguatkan penelitian terdahulu yang dibuat oleh (Pratama, 2010), Astuti (2013), (Pratiwi \& Hindasah, 2014) dan Annisa (2015) yang menyimpulkan bahwa NPL berhubungan negatif signifikan terhadap kredit perbankan.

2. $\mathrm{Uji} \mathrm{F}$

Tabel 8 Hasil Uji F

\begin{tabular}{|c|l|l|}
\hline F-stat & \multicolumn{1}{|c|}{ F-tab } & \multicolumn{1}{c|}{ Keterangan } \\
\hline 3789.381 & 3.05 & F-stat $>$ F-tab, Ho ditolak \\
\hline
\end{tabular}

Sumber: hasil olah data 
Tabel 8 memperlihatkan hasil uji $\mathrm{F}$ dapat diketahui bahwa secara bersamaan variable indepeden yaitu DPK dan NPL mempunyai hubungan signifikan terhadap jumlah saluran kredit. Hasil tersebut didapat dari angka F-statistik yang lebih besar dari nilai F-table (3789,381>3.05) dengan angka signifikansi 0,000<0,05.

\section{Penutup}

\subsection{Kesimpulan}

Berdasarkan pembahasan dan analisis data maka dapat diambil kesimpulan yaitu: (1) Dana Pihak Ketiga (DPK) berpengaruh positif signifikan terhadap jumlah penyaluran kredit; (2) NonPerforming Loan berpengaruh negatif signifikan terhadap jumlah penyaluran kredit; (3) Secara simultan terdapat pengaruh yang signifikan pada variable independen yaitu DPK dan NPL terhadap jumlah penyaluran kredit.

\subsection{Saran}

Berdasarkan hasil penelitian, maka diajukan saran-saran sebagai berikut.

1. Untuk sektor perbankan, hasil penelitian diharapkan mampu menjadi bahan rujukan dan evaluasi dalam pengelolaan perbankan terutama penghimpunan dan penyaluran kredit yang disesuaikan dengan asas perkreditan untuk meminimalisir terjadinya risiko.

2. Untuk penelitian selanjutnya, dapat menambahkan tahun periode dan variabel lainnya agar menghasilkan data yang lebih baik dan akurat.

\section{Daftar Pustaka}

Abdullah, M. (2005). Dasar-dasar Manajemen Kenangan (Edisi Kedua). Penerbitan Universitas Muhammadiyah.

Annual Report. (2020). Bursa Efek Indonesia. https://ww.idx.co.id

Balgova, M. (2016). The Economic Impact Of Reducing Non Performing Loan. In Working Paper.

Darmawan, K. (2004). Analisis Rasio-Rasio Bank. 18-21.

Dendawijaya, L. (2005). Manajemen Perbankan. Ghalia Indonesia.

Ghozali, I. (2009). Aplikasi Analisis Multivariate dengan Program SPSS. Universitas Diponegoro.

Gujarati, N. (2006). Dasar-dasar Ekonometrika. Erlangga.

Hill, R.C, et etc. (2008). Principles of Econometrics. 3.

Kasmir. (2008). Manajemen Perbankan. PT Raja Grafindo Persada.

Kiryanto, R. (2007). Langkah Terobosan Mendorong Ekspansi Kredit. Economic Review, 208.

Meydianawhati, L. (2007). Analisis Perilaku Penawaran Kredit Perbankan Kepada Sektor UMKM di Indonesia. Buletin Ekonomi, 12.

Mukhlis, I. (2011). Penyaluran Kredit Bank ditinjau dari Jumlah Dana Pihak Ketiga dan Non Performing Loan. Keuangan Dan Perbankan, 15(1), 130-138.

Mulyono, T. (2007). Manajemen Perkereditan Bagi Perbankan Komersil. BPFE.

Pratama, B. A. (2010). Analisis Faktor - Faktor Yang Mempengarubi Kebijakan Penyaluran Kredit Perbankan (Studi pada Bank Umum di Indonesia Periode Tabun 2005 - 2009). 19(2), 135-148. https://doi.org/10.14710/jbs.19.2.135-148

Pratiwi, S., \& Hindasah, L. (2014). Pengaruh Dana Pihak Ketiga, Capital Adequacy Ratio, Return Nn Asset, Net Interest Margin Dan Non Performing Loan Terhadap Penyaluran Kredit Bank 
Popy Sandra Tesalonica Hutahaen, Diharpi Herli Setyowati, Endang Hatma Juniwati

Umum Di Indonesia. Jurnal Manajemen Bisnis Universitas Mubammadiyah Yogyakarta, 5(2), 192 208.

Sentausa, S. (2009). Perbankan Minta BI Permudah Aturan. Rabu 25 Maret 2009. Kompas.com

Soedarto, M. (2004). Analisis Faktor - Faktor yang Mempengaruhi Penyaluran Kredit pada Bank

Perkreditan Rakyat (Studi Kasus pada BPR di Wilayah Kerja BI Semarang). Tesis Prodi Agister Manajemen Universitas Diponegoro Semarang.

Surat Edaran Bank Indonesia No.6/23/DPNP 2004. (2004). Bank Indonesia.

Undang-Undang No. 10 Tabun 1998. (1998). Bank Indonesia. 